\title{
Angiotensin Converting Enzyme Inhibitory Activity from Fermented Goat Milk Produced with Different Lactic Acid Bacteria
}

\author{
P. Sathya ${ }^{1 *}$, K. Radha ${ }^{1}$, C.T. Sathian ${ }^{1}$ and C. Srinivasan ${ }^{2}$ \\ ${ }^{1}$ Department of Dairy Science, College of Veterinary and Animal Sciences, \\ Mannuthy, Thrissur-680651, Kerala, India \\ ${ }^{2}$ Department of Animal Nutrition, College of Veterinary and Animal Sciences, \\ Mannuthy, Thrissur-680651, Kerala, India \\ *Corresponding author
}

\section{A B S T R A C T}

\begin{tabular}{|l|}
\hline K e y w o r d s \\
Goat milk, Lactic acid \\
bacterial cultures, \\
$\begin{array}{l}\text { Hypertension, ACE } \\
\text { inhibitory activity, } \\
\text { Fermentation. }\end{array}$ \\
\hline Article Info \\
\hline $\begin{array}{l}\text { Accepted: } \\
\text { 12 October } 2017 \\
\text { Available Online: } \\
\text { 10 December } 2017\end{array}$
\end{tabular}

Keywords

Goat milk, Lactic acid Hypertension, $A C E$ inhibitory activity,

\section{Introduction}

Milk proteins are good source of peptides with diverse biological activities. These bioactive peptides are latent or encrypted within the primary structure of native protein and can be released by enzymatic hydrolysis during gastrointestinal digestion or milk fermentation with lactic acid bacteria. They have anti oxidative, anti-carcinogenic, antimicrobial, immuno modulatory, antithrombotic, mineral binding and angiotensin converting enzyme (ACE) inhibitory activities (Nandhini et al., 2012). ACE is a dipeptidyl carboxy peptidase, key enzyme which plays a major role in regulation of blood pressure in the renin-angiotensinaldosterone system and kinin nitric oxide system. ACE raises blood pressure by converting the inactive angiotensin I (decapeptide) to the potent vasoconstrictor angiotensin II (octapeptide). It also inactivates the vasodilator, bradykinin which leads to increase in blood pressure. ACE inhibitory peptides were isolated from different food sources, such as soy proteins, fish proteins, egg proteins and maize and milk proteins. However, milk proteins appear to be the most important source of these bioactive peptides identified so far. 
The aim of this study was to determine the ACE inhibitory activity from goat milk fermented with different lactic acid bacterial cultures

\section{Materials and Methods}

Goat milk required for the study was collected from University Goat and Sheep farm, Mannuthy. The starter cultures such as Lactobacillus helveticus (NCDC 288), Lactobacillus bulgaricus (NCDC 009), Lactobacillus rhamnosus (NCDC 024), Lactobacillus plantarum (NCDC 417), Lactobacillus casei (NCDC 297), Lactobacillus paracasei subsp. paracasei (NCDC 022) and Lactobacillus acidophilus (NCDC 015) were procured from National Collection of Dairy Cultures, NDRI, Karnal, India.

\section{Preparation of fermented milk}

Goat milk was filtered to remove the extraneous matter and laboratory pasteurization was carried out at $68^{\circ} \mathrm{C}$ for 30 minutes. Then the milk was cooled to the inoculation temperature and inoculated with 3 percent of the cultures. Incubation was done at $37^{\circ} \mathrm{C}$ for $14 \mathrm{hrs}$ for the cultures $L$. plantarum NCDC 417, L. casei NCDC 297, L. paracasei subsp. paracasei NCDC 022, L. acidophilus NCDC 015. Milk samples fermented with Lactobacillus helveticus NCDC 288, Lactobacillus bulgaricus NCDC 009 and Lactobacillus rhamnosus NCDC 024 were incubated at $42^{\circ} \mathrm{C}$ for $14 \mathrm{hrs}$. Then the fermented milk samples were stored at refrigerated temperature.

\section{Determination of $\mathrm{pH}$, titratable acidity and lactic acid bacterial count of fermented milk}

$\mathrm{pH}$ of the fermented milk was determined by using digital $\mathrm{pH}$ meter (Systronics $\mathrm{pH}$ meter).
Titratable acidity was determined by the method suggested by (Ranganna, 2005). The acidity was expressed in terms of per cent lactic acid. Lactic acid bacterial count was done by pour plate method by using de Mann Rogosa Sharpe agar (MRS agar). The plates were incubated at $37^{\circ} \mathrm{C}$ for $24 \mathrm{hrs}$ for $L$. plantarum, L. acidophilus, L. casei and L. paracasei subsp paracasei. Samples inoculated with L. helveticus, L. bulgaricus and $L$. rhamnosus were incubated at $42^{\circ} \mathrm{C}$ for 24 hrs. After the incubation period, Lactic acid bacterial count was done by using a colony counter.

\section{Determination of proteolytic activity}

Measurement of proteolytic activity was done by Quantitative method (Ophthaldialdehyde method) as per Hati et al., (2015). An aliquot of $2.5 \mathrm{ml}$ of activated cultures were added to $5 \mathrm{ml}$ of $0.75 \%$ trichloro acetic acid (TCA) and allowed to stand for $10 \mathrm{~min}$ and the mixture was filtered using Whatman filter paper 42 . Then $150 \mu \mathrm{l}$ of filtrate obtained from filtration process was transferred to $3 \mathrm{ml}$ of OPA reagent and mixed properly. After incubation for $2 \mathrm{~min}$ at room temperature, the absorbance of solution was measured spectro photometrically at $340 \mathrm{~nm}$. The proteolytic activities of bacterial cultures were expressed as absorbance of free amino acid groups measured at $340 \mathrm{~nm}$.

\section{Determination of ACE inhibitory activity}

The Angiotensin Converting Enzyme inhibitory (ACE-I) activity was determined according to the method of Ramchandran et al., (2008). Briefly, 0.005 M Hippuryl-L Histidyl-L-leucine (HHL) was diluted in 0.1 $\mathrm{M}$ borate buffer containing $0.3 \mathrm{M} \mathrm{NaCl}$ at $\mathrm{pH}$ 8.3, as a substrate for the rabbit lung ACE (0.1 units $/ \mathrm{mL}$ ). Approximately, $60 \mu \mathrm{l}$ of the borate buffer was added to $200 \mu$ of the substrate solution followed by the addition of 
$30 \mu \mathrm{l}$ of the filtered sample and pre incubated at $37^{\circ} \mathrm{C}$ for $5 \mathrm{~min}$. The next step was addition of exactly $20 \mu 1$ of the enzyme solution (ACE) and incubation at $37{ }^{\circ} \mathrm{C}$ for $30 \mathrm{~min}$. The reaction was stopped by adding $250 \mu \mathrm{l}$ of $1 \mathrm{M}$ $\mathrm{HCl}$ solution and then mixing with $1.7 \mathrm{~mL}$ ethyl acetate. After 10 minutes incubation at room temperature, $1.4 \mathrm{~mL}$ of the ethyl acetate layer was removed and dried on a boiling water bath and then in an oven at $80^{\circ} \mathrm{C}$ for 30 min. The remaining residue after the removal ethyl acetate was discarded. The dried hippuric acid in the test tube was dissolved in $1 \mathrm{~mL}$ of deionised water and the absorbance of the resulting solution was measured at 228 $\mathrm{nm}$ using a UV spectrophotometer. The percent inhibition was calculated by using the following formula:

\section{$A C E$ inhibition $=1-(C-D / A-B) \times 100$}

Where,

$\mathrm{A}$ is the absorbance in the presence of $\mathrm{ACE}$ and without sample,

B is the absorbance without ACE and sample,

$\mathrm{C}$ is the absorbance with ACE and ACEinhibitory component, and

D is the absorbance with sample but without ACE.

\section{Results and Discussion}

pH

Mean $\mathrm{pH}$ of goat milk samples fermented with different lactic acid bacterial cultures are presented in Table 1. $\mathrm{pH}$ values of fermented milk samples ranged from $4.535 \pm 0.074$ to 5.921 \pm 0.153 . Milk fermented with $L$. acidophilus 015 showed highest $\mathrm{pH}$ value whereas, milk fermented with $L$. helveticus 288 showed lowest $\mathrm{pH}$ value. Hati et al.,
(2015), reported that $\mathrm{pH}$ of fermented milk samples ranged from 3.8 to 4.8 for different strains like L. helveticus (MTCC 5463), $L$. rhamnosus (NS4 and NS6) and L. bulgaricus (009). In their study the cultures were inoculated at 1 percent level. In the present study the cultures were inoculated at 3 percent level. However, the selected cultures in the present study had low acid production potential. Hence, the fermented milk samples showed high $\mathrm{pH}$ values.

\section{Titratable acidity}

The mean titratable acidity of milk samples fermented with different lactic acid bacterial cultures are presented in Table 2. Titratable acidity of fermented milk samples ranged from $0.276 \pm 0.011$ to $0.833 \pm 0.043$ percent lactic acid. The highest titratable acidity was noticed in L. helveticus NCDC 288 and lowest titratable acidity was noticed in $L$. acidophilus 015. Hati et al., (2015) reported that milk fermented with $L$. bulgaricus (NCDC 009), L. rhamnosus NS4 and NS6, L. helveticus had 0.6, $0.78,0.97$ and 0.831 percent lactic acid respectively. Shu et al., (2015) also reported similar findings. Titratable acidity of fermented milk samples varied due to the difference in bacterial species, strains, inoculum level, and incubation time.

\section{Lactic acid bacterial counts}

Mean Lactic acid bacterial count of milk samples fermented with different lactic acid bacterial cultures are presented in Table 3. Lactic acid bacterial count of fermented milk samples ranged from $9.079 \pm 0.064$ to $10.042 \pm 0.056 \log \mathrm{cfu} / \mathrm{mL}$. Highest Lactic acid bacterial count was noticed in milk fermented with L. bulgaricus 009 and the count was $10.042 \pm 0.056 \log \mathrm{cfu} / \mathrm{mL}$. The lowest count was noticed in milk fermented with $L$. paracasei subsp paracasei 022 and it was 
$9.079 \pm 0.064 \log \mathrm{cfu} / \mathrm{mL}$. Nejati et al., (2013) found that lactic acid bacterial count of fermented milk prepared with L. plantarum PU11 was $\log \mathrm{cfu} / \mathrm{mL}$.

Table.1 Mean $\mathrm{pH}$ of goat milk fermented with different lactic acid bacterial cultures

\begin{tabular}{|c|l|c|}
\hline S.NO & \multicolumn{1}{|c|}{ CULTURE NO } & $\begin{array}{c}\text { INNOCULAM SIZE } \\
(3 \text { PER CENT) }\end{array}$ \\
\hline 1. & Lactobacillus helveticus 288 & $4.535 \pm 0.074^{\mathrm{a}}$ \\
\hline 2. & Lactobacillus bulgaricus 009 & $5.613 \pm 0.093^{\mathrm{de}}$ \\
\hline 3. & Lactobacillus rhamnoasus 024 & $4.971 \pm 0.172^{\mathrm{b}}$ \\
\hline 4. & Lactobacillus plantarum 417 & $5.240 \pm 0.077^{\mathrm{bc}}$ \\
\hline 5. & Lactobacillus casei 297 & $5.326 \pm 0.094^{\mathrm{cd}}$ \\
\hline 6. & Lactobacillus paracaseissp.paracasei 022 & $5.695 \pm 0.119^{\mathrm{de}}$ \\
\hline 7. & Lactobacillus acidophilus 15 & $5.921 \pm 0.153^{\mathrm{e}}$ \\
\hline & F value & $16.186^{* *}$ \\
\hline & p-value & $<0.001$ \\
\hline
\end{tabular}

Each value is a mean of six observations with $\mathrm{SE}$

Means with different superscripts within same column differ significantly $(\mathrm{p}<0.001)$

**Significant at 0.01 level

Table. 2 Titratable acidity of goat milk fermented with different lactic acid bacteria

\begin{tabular}{|c|l|c|}
\hline S.NO & \multicolumn{1}{|c|}{ CULTURE NO } & $\begin{array}{c}\text { INNOCULAM SIZE (3 } \\
\text { PER CENT) }\end{array}$ \\
\hline 1. & Lactobacillus helveticus 288 & $0.833 \pm 0.043^{\mathrm{d}}$ \\
\hline 2. & Lactobacillus bulgaricus 009 & $0.41 \pm 0.027^{\mathrm{b}}$ \\
\hline 3. & Lactobacillus rhamnoasus 024 & $0.589 \pm 0.048^{\mathrm{c}}$ \\
\hline 4. & Lactobacillus plantarum 417 & $0.566 \pm 0.026^{\mathrm{c}}$ \\
\hline 5. & Lactobacillus casei 297 & $0.526 \pm 0.056^{\mathrm{c}}$ \\
\hline 6. & Lactobacillus paracaseissp.paracasei 022 & $0.366 \pm 0.042^{\mathrm{ab}}$ \\
\hline 7. & Lactobacillus acidophilus 15 & $0.276 \pm 0.011^{\mathrm{a}}$ \\
\hline & F-value & $22.007^{* *}$ \\
\hline & p-value & $<0.001$ \\
\hline
\end{tabular}

Each value is a mean of six observations with SE

Means with different superscripts within same column differ significantly $(p<0.001)$

**Significant at 0.01 level 
Table.3 Lactic acid bacterial count of goat milk fermented with different lactic acid bacterial cultures

\begin{tabular}{|c|c|c|}
\hline S.No & Culture No & Inoculum Size ( 3 per cent) \\
\hline 1. & Lactobacillus helveticus 288 & $9.355 \pm 0.042^{\mathrm{b}}$ \\
\hline 2. & Lactobacillus bulgaricus 009 & $10.042 \pm 0.056^{\mathrm{e}}$ \\
\hline 3. & Lactobacillus rhamnoasus 024 & $9.695 \pm 0.025^{\mathrm{d}}$ \\
\hline 4. & Lactobacillus plantarum 417 & $9.570 \pm 0.062^{\mathrm{cd}}$ \\
\hline 5. & Lactobacillus casei 297 & $9.258 \pm 0.081^{b}$ \\
\hline 6. & Lactobacillus paracasei subsp. paracasei 022 & $9.079 \pm 0.064^{\mathrm{a}}$ \\
\hline 7. & Lactobacillus acidophilus 15 & $9.426 \pm 0.046^{\mathrm{bc}}$ \\
\hline \multicolumn{2}{|r|}{ F-value } & $31.196^{* * *}$ \\
\hline \multicolumn{2}{|r|}{ p-value } & $<0.001$ \\
\hline
\end{tabular}

Each value is a mean of six observations with SE

Means with different superscripts within same column differ significantly $(\mathrm{p}<0.001)$. **Significant at 0.01 level

Table.4 Proteolytic activity of goat milk fermented with different lactic acid bacterial cultures

\begin{tabular}{|c|l|c|}
\hline S.No & \multicolumn{1}{|c|}{ Culture No } & Inoculum Size (3 per cent) \\
\hline 1. & Lactobacillus helveticus 288 & $0.415 \pm 0.029^{\mathrm{a}}$ \\
\hline 2. & Lactobacillus bulgaricus 009 & $0.513 \pm 0.019^{\mathrm{b}}$ \\
\hline 3. & Lactobacillus rhamnoasus 024 & $0.418 \pm 0.027^{\mathrm{a}}$ \\
\hline 4. & Lactobacillus plantarum 417 & $0.519 \pm 0.019^{\mathrm{b}}$ \\
\hline 5. & Lactobacillus casei 297 & $0.500 \pm 0.013^{\mathrm{ab}}$ \\
\hline 6. & Lactobacillus paracasei subsp. paracasei 022 & $0.619 \pm 0.049^{\mathrm{c}}$ \\
\hline 7. & Lactobacillus acidophilus 15 & $0.506 \pm 0.032^{\mathrm{b}}$ \\
\hline & F-value & $5.623^{* *}$ \\
\hline & p-value & $<0.001$ \\
\hline
\end{tabular}

Each value is a mean of six observations with $\mathrm{SE}$

Means with different superscripts within same column differ significantly $(\mathrm{p}<0.001)$. **Significant at 0.01 level

Table.5 Angiotensin converting enzyme inhibitory activity of goat milk fermented with different lactic acid bacterial cultures

\begin{tabular}{|c|c|c|c|}
\hline S.No. & Culture No. & $\begin{array}{l}\text { Inoculum Level ( } 3 \text { per cent) } \\
\text { (per cent) }\end{array}$ & $\begin{array}{l}\text { Inoculum Level ( } 3 \text { per cent) } \\
\left(\text { IC }_{\mathbf{5 0}} \text { value } \mathbf{~} \mathbf{g} / \mathbf{m L}\right)\end{array}$ \\
\hline 1. & Lactobacillus helveticus 288 & $65.121 \pm 0.963^{\mathrm{a}}$ & 0.082 \\
\hline 2. & Lactobacillus bulgaricus 009 & $87.075 \pm 1.709^{d}$ & 0.033 \\
\hline 3. & Lactobacillus rhamnoasus 024 & $88.660 \pm 1.774^{\mathrm{d}}$ & 0.031 \\
\hline 4. & Lactobacillus plantarum 417 & $90.700 \pm 1.276^{\mathrm{d}}$ & 0.028 \\
\hline 5. & Lactobacillus casei 297 & $68.196 \pm 1.974^{\mathrm{a}}$ & 0.073 \\
\hline 6. & Lactobacillus paracaseissp.paracasei 022 & $81.876 \pm 2.191^{\mathrm{c}}$ & 0.043 \\
\hline 7. & Lactobacillus acidophilus 15 & $76.363 \pm 1.786^{b}$ & 0.054 \\
\hline \multicolumn{2}{|r|}{ F-value } & $35.053^{* *}$ & \\
\hline \multicolumn{2}{|r|}{ p-value } & $<0.001$ & \\
\hline
\end{tabular}

Each value is a mean of six observations with $\mathrm{SE}$

Means with different superscripts within same column differ significantly $(\mathrm{p}<0.001)$. **Significant at 0.01 level 


\section{Proteolytic activity}

Mean proteolytic activity of different lactic acid bacterial cultures are presented in Table 4. The Proteolytic activity varied from $0.415 \pm 0.029$ to $0.619 \pm 0.049$. The highest proteolytic activity $(0.619 \pm 0.049)$ was observed in milk fermented with Lactobacillus paracasei subsp. paracasei 022. Milk fermented with Lactobacillus helveticus 288 showed the lowest proteolytic activity $(0.415 \pm 0.029)$. The extent of proteolysis varied among species and found to be strain dependant. Donkor et al., (2007a) reported that proteolytic activity of $L$. helveticus was 0.592. In the present study proteolytic activity of L. helveticus was 0.415 . The variation in proteolytic activity can be attributed to the difference in strains.

\section{ACE inhibitory activity}

Mean ACE inhibitory activity of milk samples fermented with different lactic acid bacterial cultures are presented in Table 5 . ACE inhibitory activity ranged from $65.121 \pm 0.963$ to $90.700 \pm 1.276$ per cent. The highest ACE inhibitory activity was observed in goat milk fermented with Lactobacillus plantarum 417 . The value was $90.700 \pm 1.276$ per cent. The lowest ACE inhibitory activity was observed in goat milk fermented with Lactobacillus heleticus 288 and the activity was $65.121 \pm 0.963$ per cent. Nandhini et al., (2012) have studied the ACE- inhibitory activity and antioxidant properties of goat milk fermented with Lactobacillus plantarum. They have reported that the ACE inhibitory activity of the fermented milk was $88.96 \%$. In a study conducted by Hati et al., (2015) milk fermented with Lactobacillus rhamnosus and Lactobacillus delbruckii exhibited highest proteolytic activity and ACE inhibitory activity. Shu et al., (2015) reported that ACE inhibitory activity of milk fermented with $L$. plantarum varied from 77.95 to $81.25 \%$. In this study Lactobacillus plantarum (417) had ACE inhibitory activity of $90.70 \%$ at 3\% inoculum level. There was significant positive correlation between proteolytic activity and ACE inhibitory activity.

Goat milk fermented with different lactic acid bacterial cultures had ACE inhibitory activity ranging from 65.12 to $90.70 \%$. Among seven LAB cultures, milk fermented with Lactobacillus plantarum (NCDC 417) showed maximum ACE inhibitory activity followed by Lactobacillus rhamnosus (NCDC 024). There was a significant positive correlation between proteolytic activity and ACE inhibitory activity. There is a great potential to develop functional dairy products with antihypertensive activity by incorporating specific lactic acid bacterial cultures capable of releasing ACE inhibitory peptides in the preparation of fermented dairy products.

\section{References}

Chen, G.W., Tsai, J.S. and Pan, B.S. 2007. Purification of angiotensin I converting enzyme inhibitory peptides and antihypertensive effect of milk produced by protease-facilitated lactic fermentation. Int. Dairy J. 17(6): 641647.

Donkor, O.N., Henriksson, A., Vasiljevic, T. and Shah, N.P. 2007a. Proteolytic activity of dairy lactic acid bacteria and probiotics as determinant of growth and in vitro angiotensin-converting enzyme inhibitory activity in fermented milk. Lait, 87: 21-38.

Hati, S., Sreeja, V., Solanki, J. and Prajapati, J.B. 2015. Significance of proteolytic microorganisms on ACE inhibitory activity and release of bioactive peptides during fermentation of milk. Indian J. Dairy Sci. 68: 584-591. 
Nandhini, B., Angayarkanni, J. and Palanisamy, M. 2012. Angiotensin converting enzyme inhibitory activity and antioxidant properties of goat milk hydrolysates. Int. J. Pharm. Pharm. Sci. 4: 367-370.

Nejati, F., Rizzello, C.G., Cagno, R.D., Zeinoddin, M.S., Diviccaro, A., Minervini, F. and Gobbetti, M. 2013. Manufacture of a functional fermented milk enriched of Angiotensin converting enzyme (ACE) inhibitory peptides and $\gamma$-amino butyric acid (GABA). Food Sci. Technol. 51(1): 183-189.

Ramchandran, L. and Shah, N.P. 2008. Proteolytic profiles and angiotensin converting enzyme and alphaglucosidase inhibitory activities of selected lactic acid bacteria. J. Food Sci. 73(2): 75-81.

Ranganna, R. 2005. Hand book of analysis and quality control for fruit and vegetable products, 2nd edn. Tata McGrraw-Hill Publishing Company Limited, New Delhi.

Shu, G., Yang, H., Chen, H., Zhang, Q. and Tian, Y. 2015. Effect of incubation time, inoculum size, temperature, pasteurization time, goat milk powder and whey powder on ACE inhibitory activity in fermented milk by $L$. plantarum LP69. Acta Sci. Pol. Technol. Aliment. 14(2): 107-116.

\section{How to cite this article:}

Sathya, P., K. Radha, C.T. Sathian and Srinivasan, C. 2017. Angiotensin Converting Enzyme Inhibitory Activity from Fermented Goat Milk Produced with Different Lactic Acid Bacteria. Int.J.Curr.Microbiol.App.Sci. 6(12): 1670-1676. doi: https://doi.org/10.20546/ijcmas.2017.612.188 